\title{
A Win-Win Solution Concerning Tax Planning for the Real Estate Development Enterprises and Government
}

\author{
Zhifei Liu, Ya Wen, Cheng Huang \\ Guangdong University of Technology, Guangzhou, China \\ Email: lzf600@yeah.net \\ Received 15 April 2014; revised 12 May 2014; accepted 5 June 2014 \\ Copyright $@ 2014$ by authors and Scientific Research Publishing Inc. \\ This work is licensed under the Creative Commons Attribution International License (CC BY). \\ http://creativecommons.org/licenses/by/4.0/

(c) (i) Open Access

\begin{abstract}
Along with the advancement of China's new urbanization, whether the real estate development enterprises can make a contribution to the new urbanization is becoming the key to their healthy and sustainable development. This article analyzes how to select LAT tax planning schemes in the background of the new urbanization; therefore, the real estate development enterprises can achieve a win-win situation with the new urbanization. We hope to provide some help to LAT tax planning work for the real estate development enterprises.
\end{abstract}

\section{Keywords}

New Urbanization, Real Estate, LAT, Tax Planning

\section{Introduction}

Urbanization is the course of history changing from traditional agricultural society in which the agricultural population accounts for a large proportion to modern civilized society that the non-agricultural population accounts for the majority [1]. There will be no doubt that it brings a lot of consumer demand, the huge public services and welfare facilities construction, infrastructure construction, housing property, industrial and commercial real estate and other investment demand during this transformation process. And compared with the traditional formulation of urbanization, new urbanization gives more prominent to the quality connotation, which is to promote urbanization focusing on quantity expansion in the past to pay attention to improve the intrinsic quality. So the current high prices and the trend to rise further have formed a stumbling block in the new urbanization process. As we all know, with the urbanization pushing China's future economic, it will bring great opportunity of development to real estate development enterprises certainly. But in front of the big opportunity, 
real estate development enterprises must have a correct understanding of new urbanization development in order to obtain long-term development. They must believe that only assisting the new urbanization construction can they achieve the long-term healthy development of the enterprise.

For realizing the target of assisting new urbanization construction, real estate development enterprise must adjust the development strategy and set up a win-win concept with the new urbanization construction [2]. So what's the influence on land value-added tax planning methods due to the adjustment of real estate development enterprises?

\section{The Real Estate Should Be the Supporting Industries of Urbanization Construction and the Land Value-Added Tax Planning Scheme}

After the implementation of housing monetization reform, under the impetus of the privatization real estate has been regarded as the leading role of the urbanization development with the promotion of housing privatization and commercialization [3]. Now in the new period of the urbanization construction the real estate development enterprises should correctly locate their positions and recognize the real estate should be just a supporting industry. Services for the new urbanization should be the direction for their development. In particular, real estate development enterprises must bear such a mission: build houses to satisfy the needs of the people, develop plant buildings and other infrastructure in accordance with the regional economic development. They should do a good job of supporting services in the urbanization process, not be ahead or backward [3].

Therefore, real estate development enterprises should not only consider profit when making a development project decision. They should regard boosting the development of urbanization as a strategic goal. In most cases, driven by the benefit real estate development enterprises tend to choose projects which have low cost and high profit without regard to the long-term objective of the development of urbanization. Because the cost of development, taxes and land cost is different when having projects development in the cities and towns at the same time [4]. Nowadays real estate development enterprises play a role as supporting industries in the urbanization process. The starting point of decision-making should be promoting the development of urbanization.

In consideration of this change, how should real estate development enterprises consider the land value-added tax planning?

\subsection{Adjust the Development Costs}

When real estate development enterprises have projects development in cities and towns at the same time, the development cost, taxes and land cost will have differences between the cities and towns due to price and other reasons. So the land increment rate will also be different [5]. The higher or lower land increment rate will actually increase tax burden of enterprises. Real estate development enterprises should make decisions based on the purpose of assisting urbanization development. Real estate development enterprises can adjust the development cost occurring in cities and towns at the same time to the extreme. Through such a thing the overall increment rate is reduced and tax burden is the lightest.

\subsection{The Tax Planning of the Construction Mode}

Real estate development enterprises should be the supporting industries. Compared with the traditional real estate development mode - the sale after development, cooperative housing, agent housing or joint ventures can reflect the supporting role better [6]. In particular, newly established industrial enterprises need to build factories. At the same time the enterprises need to solve the housing problem due to the accumulation of the industry and the tertiary industry. And the industrial enterprises know the specific needs for workshop and housing clearly, so if the real estate development enterprises can negotiate with the industrial enterprises in time and take the way of cooperating housing, joint operation or joint ventures which will be more targeted. And this will meet the needs of the enterprise development more timely and can better reflect the supporting role of real estate development enterprises for the new urbanization.

Then how to choose the relevant land VAT tax planning for real estate development enterprises?

\subsubsection{Cooperative Housing}

Cooperative housing refers to one provides land access, the other or multilateral funds the project. And they de- 
velop real estate project cooperating with each other. And the government will suspend the value-added tax on land for private use in proportion after building. But people need to fill land value-added tax for the transfer use after the completion. Due to save the land value-added tax, financing costs, cost of sales, public relations, etc., the price is more than $40 \%$ lower than the commercial house and can get house proprietary certificate at the same time.

Real estate development enterprises and industrial company will both benefit a lot making use of this planning ideas actively and reasonably. To be specific, A, the real estate development company, bought a piece of land and obtained the land use right. A will cooperate with B factory to build office buildings for private use. B factory is the stakeholder. For B factory, according to its capital contribution to the offices, the comprehensive cost will exclude land value-added tax, so its cost is lower than the same commercial housing. For A, the real estate development enterprise, due to its exempted from of land value-added tax, has reflected the tax saving effect.

\subsubsection{Agent Housing}

The way of agent housing will not transfer the ownership of real estate property during the whole development process, so it is not within the scope of land VAT. We only need to pay business tax rate of $3 \%$ in accordance with the construction industry. The way of agent housing can also be in accordance with the requirements of customers about the design and construction, meet customer needs better and can reflect the supporting role of the real estate in the new urbanization construction.

\subsubsection{Joint Ventures}

Provisional Regulations on land value-added tax indicates that for real estate investment and joint investment that the land is made as an investment or joint conditions, land value-added tax is suspended. To be specific, A real estate development enterprise invest in B industrial enterprises or joint on both sides with his house. For A real estate development enterprise, it can reduce the tax burden and increase profits because the land valueadded tax and business tax shall be exempted. To B enterprise, it can obtain a real estate at a relatively low cost due to the reduction of tax burden.

\section{The Housing Supply Structure Should Be Adapted to the Needs of the New Type of Urbanization and Land Value-Added Tax Planning Scheme According to the Change}

As mentioned in the introduction, high housing price has become the resistance of the urbanization development recently, thus the government must control the trend of the rising prices. And they can control the prices from the perspective of market supply. That is to say, they can increase the market supply of ordinary commercial housing through policy guidance massively, especially small and medium-sized commercial housing. Ordinary commodity housing will inevitably be the main development projects led by the government and also inevitably become the main development project of the real estate development enterprises. And what's the land valueadded tax planning in term of the ordinary commodity housing?

In view of the ordinary commodity housing, the preferential tax mainly include: taxpayers who build standard housing for sale will exempt from the land value increment tax in case that the appreciation value doesn't exceed $20 \%$ of the amount of deductible items. Otherwise it shall pay all its appreciation tax in accordance with the regulations. So we can consider planning methods from the perspective of controlling the appreciation.

\subsection{Adjust the Sales}

When to determine the price of real estate sales, real estate development enterprises should balance the benefits from the prices and tax saving benefit getting from the preferential tax policy.

Case 1: A real estate development company builds a standard residential property, achieving sales revenue of 10.32 million Yuan at a normal price. The deductions are 8.4 million Yuan, including real estate development costs which is 2 million Yuan, land cost which is 1.8 million Yuan, taxes related to the transfer of real estate which is 800,000 Yuan, 400,000 Yuan of the cost of real estate development (allow deductions). And according to the regulations of the tax law, the additional deduction $=$ (land costs + real estate development costs) $\times 20 \%$, so the project can be applied to deduct $(180+420) \times 20 \%=1.2$ million Yuan. Thus the project increment rate is 
$(1032-180-420-40-80-120) /(180+420+40+80+420)=22.85 \%$. With reference to the land valueadded tax rates, the taxpayer should pay land value-added tax at a reduced rate of $30 \%$. The tax payable of the project is: $(1032-180-420-40-80-120) \times 30 \%=576,000$ Yuan. After-tax profits: $1032-180-420-40$ $-80-120-57.6=$ RMB 1.344 million.

If the real estate development company conducts land value-added tax planning, a small amount of lower housing sales revenue will be 10.08 million Yuan. The increment rate: $(1008-180-420-40-80-120) /(180$ $+180+40+420+120)=20 \%$. According to the standard housing tax breaks, the enterprises don't have to pay the land value-added tax. The after-tax profits: $1008-180-420-40-80-120=1.68$ million Yuan. So you can see the profits of company increase by RMB 336,000 by adjusting the tax planning of the sales.

\subsection{Adjust the Deductions}

Real estate development enterprises can reduce the amount of land value-added tax through applying accounting standards, increasing the project which can be deducted, reducing appreciation rate without a change in housing sales price. At the same time it will improve the quality of the building and the housing facilities so as to make the enterprise competitive advantage.

The above two planning methods are both effective. The first method reduces the selling price, makes the migrant workers obtain the real discount when purchasing their house in the city. The second method, although it doesn't directly reduce prices, it does improve the residential environment and the quality of housing. Compared with other residential real estate in the market the cost-effective is higher. It is also a benefit for migrant workers and can promote urbanization.

\subsection{Adjusting Accounting Methods}

For a moderate amount of high-grade residence in order to meet the market demand such as villa room, can consider to merge accounting to make comprehensive increment rate reducing and reduce the tax payable.

\subsection{Adjust the Renovation Costs}

For some of the unsold and developing high-grade residence, we can give the high-grade residential fine decoration and unique design, and then sell them [6]. We can increase the amount of the deductible items and reduce the increment rate reasonably. What's more this makes the high-grade residential stand out. And it is more advantageous to seize market share and also can reduce the tax payable at the same time. Of course, the high-grade residence requests to respect the customer wishes and consider market demand at the same time. This article is just to provide planning ideas.

\section{Conclusion}

THE Land VAT tax planning scheme of this paper is based on the request for real estate development enterprises to adapt to the new urbanization. Compared to the traditional planning methods such as interest expense planning, transfer of payments planning focusing on tax saving, the paper considers the macro policy in terms of the development strategy of assisting urbanization. So it can give some targeted suggestions for real estate development enterprises in new stage of urbanization. But we will certainly encounter a lot of twists and turns when extending the theory into practice, so the real estate development enterprises should pay more attention to details in the practical work.

\section{References}

[1] Yin, B.C. and Huang, H.T. (2013) The Development and Regulation of Real Estate Industry in the Context of New Urbanization. Study \& Exploration, 4, 81-85.

[2] Guo, X.F. and Zhang, X. (2013) The Analysis of Land VAT Tax Planning Based on Real Estate Enterprises. Friends of Accounting, 10, 108-110.

[3] Fang, L.M. (2013) Become the Protagonist for Supporting-The Orientation of Real Estate in New Urbanization by Weixin Liu. China Real Estate Market, 3, 21-23

[4] Wu, X.P. and Yao, Y.Y. (2013) The Analysis of Land Value-Added Tax Planning for Real Estate Development Enter- 
prise. Financial Communication, 8, 60-61

[5] Liu, X.L. and Tan, G.R. (2009) The Planning of Land Value-Added Tax with Real Estate Price Strategy. Finance and Accounting Monthly, 5, 16-18.

[6] Yang, S.J., Xu, L.Q. and Huang, Y.Q. (2009) Real Estate Company’s Scale, Management Level and Land VAT Tax. Finance and Accounting Monthly, 9, 20-21. 
Scientific Research Publishing (SCIRP) is one of the largest Open Access journal publishers. It is currently publishing more than 200 open access, online, peer-reviewed journals covering a wide range of academic disciplines. SCIRP serves the worldwide academic communities and contributes to the progress and application of science with its publication.

Other selected journals from SCIRP are listed as below. Submit your manuscript to us via either submit@scirp.org or Online Submission Portal.
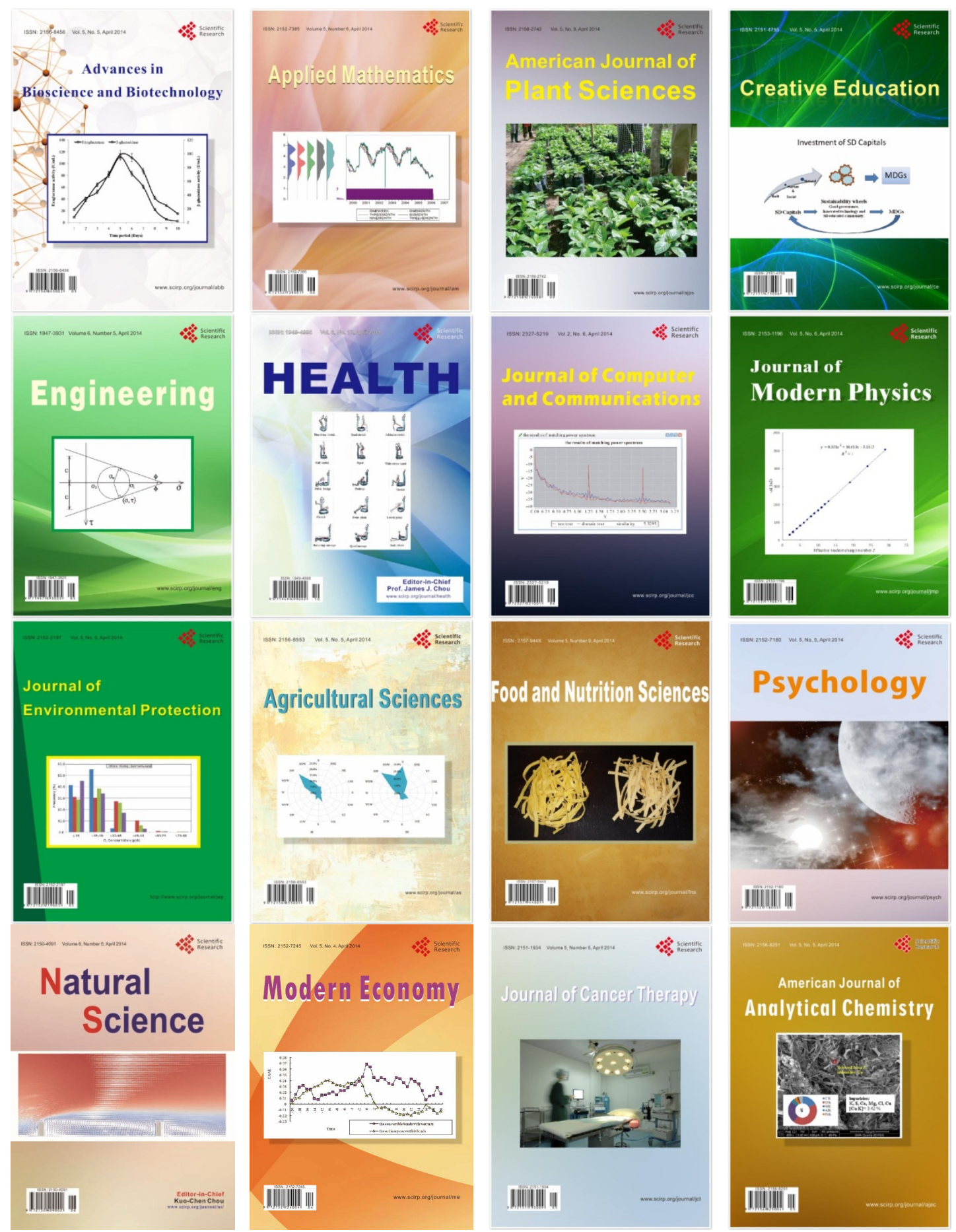